\title{
Kesiapan Sekolah, Kematangan Sosial, dan Prestasi Belajar pada Peserta Didik Kelas 1 Sekolah Dasar di bawah Usia 7 Tahun
}

\author{
Martha Kurnia Asih'1), Retno Ristiasih Utami'2) \\ Fakultas Psikologi, Universitas Semarang, Semarang, Indonesia ${ }^{\left.1{ }^{12}\right)}$ \\ marthakurniaasih@yahoo.com
}

\begin{abstract}
Abstrak. Penelitian ini bertujuan untuk mengetahui apakah prestasi belajar pada peserta didik kelas 1 Sekolah Dasar di bawah usia 7 tahun bisa diprediksi melalui kesiapan sekolah dan kematangan sosialnya. Data prestasi belajar (Y) diperoleh lewat nilai rapor, kesiapan sekolah (X1) diperoleh melalui tes kesiapan sekolah NST sedangkan kematangan sosial (X2) diperoleh melalui tes Vineland Social Maturation Scale (VSMS). Subjek penelitian adalah peserta didik kelas 1 yang usianya di bawah 7 tahun. Sampel diambil melalui teknik insidental sampling. Hasil menunjukkan bahwa koefisien Korelasi ganda (R) antara X1, X2 dan Y sebesar 0,551 dan $\mathrm{p}<0,05$ artinya ada hubungan antara kesiapan sekolah (X1) dan kematangan sosial (X2) dengan prestasi belajar (Y) dengan sumbangan sebesar $30.3 \%$. Secara parsial kesiapan sekolah berpengaruh terhadap prestasi belajar, tetapi kematangan sosial tidak memengaruhi prestasi belajar.
\end{abstract}

Kata kunci: kematangan sosial; kesiapan sekolah; prestasi belajar 


\section{Pendahuluan}

Setiap individu selalu mengalami proses belajar dalam kehidupannya, dengan belajar akan memungkinkan individu untuk mengadakan perubahan di dalam dirinya. Perubahan ini dapat berupa penguasaan suatu kecakapan tertentu, perubahan sikap, memiliki ilmu pengetahuan yang berbeda dari sebelum seseorang melakukan proses pembelajaran. Sebagaimana yang dikemukakan Dalyono (dalam Mulyani; 2012) bahwa belajar merupakan suatu kegiatan untuk mengadakan perubahan di dalam diri seseorang yaitu: perubahan tingkah laku, sikap, kebiasaan, ilmu pengetahuan, keterampilan dan sebagainy. Perubahanperubahan ini merupakan perbuatan belajar yang diinginkan, karena itu dapat dikatakan bahwa perubahan yang diinginkan akan menjadi tujuan dari proses pembelajaran. Untuk mencapai tujuan pembelajaran tersebut, maka seseorang harus memiliki kesiapan.

Kesiapan individu akan membawa individu untuk siap memberikan respon terhadap situasi yang dihadapi melalui cara sendiri. Seperti yang diungkapkan oleh Slameto (2010) bahwa kesiapan adalah keseluruhan semua kondisi individu yang membuatnya siap untuk memberikan respon atau jawaban di dalam cara tertentu terhadap situasi tertent. Kondisi tertentu yang dimaksud adalah kondisi fisik dan psikisnya, sehingga untuk mencapai tingkat kesiapan yang maksimal diperlukan kondisi fisik dan psikis yang saling menunjang kesiapan individu tersebut dalam proses pembelajaran. Kesiapan individu sebagai seorang peserta didik dalam belajar akan menentukan kualitas proses dan prestasi belajar peserta didik. Kesiapan diri peserta didik sangat penting untuk meraih keberhasilan dalam kegiatan belajar. Keberhasilan peserta didik melakukan kesiapan sebelum mengikuti pelajaran dapat menentukan kesuksesan peserta didik dalam belajar, sehingga akan mempengaruhi prestasi belajar peserta didik. Berhasil tidaknya suatu pembelajaran tergantung kepada bagaimana proses belajar yang dialami oleh peserta didik. Sebagaimana yang dikemukakan Slameto (2010) ada dua faktor yang mempengaruhi keberhasilan peserta didik dalam belajar yaitu: Faktor ekstern (yang berasal dari luar diri peserta didik) dan intern (dari dalam diri siwa). Faktor ekstern yaitu faktor yang berasal dari luar diri individu seperti 
lingkungan keluarga, sekolah dan masyarakat, sedangan faktor intern yaitu tiga tahap bagian yaitu faktor kelelahan (kelelahan jasmani dan kelelahan rohani), faktor jasmaniah (kesehatan, cacat tubuh) dan faktor psikologis (intelegensi, perhatian, minat, bakat, motif, kematangan, keterampilan dan kesiapan belajar). Anak-anak uang mengulang kelas (kurang berprestasi) pada umumnya adalah anak-anak yang tidak memasuki pendidikan prasekolah sebelum masuk SD. Mereka adalah anak yang belum siap dan tidak dipersiapkan oleh orang tuanya memasuki SD. Permasalahan utama anak yang baru masuk SD adalah school readiness, disamping banyak hal yang melatarbelakangi kondisi anak mau SD, seperti : kondisi fisik bawaan anak dan kondisi fisik rumah yang sangat mempengaruhi tumbuh kembang anak; kondisi psikososial anak di rumah; perbedaan pendidikan di rumah dengan di sekolah; saat belajar di rumah, interaksi terjadi antara satu orang dengan satu orang lainnya, misalnya antara satu orang guru dengan siswa satu kelas; anak tumbuh dengan kecerdasan yang berbeda (individual differential treatment).

Persiapan bersekolah anak usia dini yang akan memasuki jenjang sekolah dasar (SD) menunjukkan ketatnya persaingan sehingga menyebabkan orangtua berupaya meningkatkan kompetensi anak sedini dan semaksimal mungkin termasuk di tingkat pra sekolah. Beberapa ibu mengeluhkan perilaku anaknya yang belum lancar menulis dan berhitung padahal direncanakan tahun pelajaran baru anak-anak tersebut hendak masuk ke SD. Kesiapan bersekolah acap kali hanya didasarkan pada kemampuan membaca, menulis dan berhitung yang merupakan aspek kognitif saja. Berdasar informasi dari guru kelas 1 maupun panitia penerimaan peserta didik baru, menyampaikan bahwa kemampuan anak dalam menulis dan membaca sederhana menjadi persyaratan diterimanya anak menjadi peserta didik pada sekolah dasar Afifah dan Dwisusari (2016).

Kondisi-kondisi tersebut, menyiratkan bahwa kesiapan sekolah nampaknya sebagian orang tua dan pihak sekolah hanya menitikberatkan pada kemampuan kognitif saja, namun kurang menyentuh aspek sosial. Sehingga beberapa fakta yang terjadi, beberapa peserta didik pada SD awal atau calon peserta didik sekolah dasar nampaknya mereka cukup menguasai persoalan baca tulis dan hitung 
sederhana, namun mereka masih belum mampu mengurus keperluan mereka sendiri maupun dalam beradaptasi di lingkungan sekolah yang baru. Hal tersebut, sebagaimana dikemukakan oleh Kustimah (2008) berdasar penelitian tentang kesiapan sekolah anak usia TK yang menyatakan bahwa sebanyak 22\% dari responden sebanyak 213 anak belum mencapai kematangan yang optimal pada aspek pengertian dan objek dan penilaian terhadap situasi. Pemahaman terhadap situasi merupakan dasar bagi anak untuk menyesuaikan diri dengan aturan, baik aturan formal maupun aturan informal dalam bersosialisasi dengan teman sebayanya. Ketidakmampuan anak untuk memahami nilai-nilai sosial akan menyulitkan anak untuk bisa diterima oleh teman sebayanya, sehingga menghambat sosialiasinya.

Seiring proses tumbuh kembangnya, seorang anak akan melalui tahaptahap perkembangan dengan tugas perkembangan yang berbeda-beda, keberhasilan pencapaian suatu tugas perkembangan di suatu tahap akan membantu kelancaran tahap berikutnya. Hal ini menunjukkan bahwa anak dikatakan berkembang secara normal apabila anak dapat menyelesaikan tugastugas yang harus dijalaninya maka dapat dikatakan bahwa anak mengalami hambatan dalam perkembangannya. Secara umum, kesesuaian antara perkembangan anak dengan apa yang harus dicapainya dilihay melalui kematangan sosialnya.

Kematangan sosial adalah dimilikinya kemampuan perilaku sebagai kinerja yang menunjukkan kemampuan berpartisipasi dalam lingkungan anak, yang ditunjukkan anak sesuai dengan tahap perkembangannya. Pada usia kanak-kanak awal kematangan sosial ditunjukkan dengan perilaku antara lain: mampu menunjukkan sikap bekerja sama dalam kelompok, berani menampilkan diri sesuai dengan minatnya, dapat menunjukkan sikap berbagi, dapat bersikap sesuai norma lingkungan kecil, mampu bersikap simpati dan empati yang masih sederhana, dapat bersikap ramah, tidak egois, suka meniru perilaku positif lingkungannya, serta dapat memberi kasih saying pada orang yang dekat (Prihaningsih dalam Wulandari, 2008). Kematangan sosial yang dimiliki anak akan mempermudah dirinya untuk berorientasi dan bersosialisasi dengan dunia luar 
yaitu lingkungan masyarakat. Kematangan sosial juga akan mempermudah dalam melaksanakan hubungan sosial secara mandiri, dalam arti seseorang tidak akan berkembang menjadi individu yang tergantung pada lingkungan sosialnya.

Pendidikan di Sekolah Dasar adalah pintu pertama bagi anak untuk masuk jenjang pendidikan selanjutnya. Jenjang ini merupakan jenjang pendidikan yang penting sebagai langkah persiapan anak untuk mendapatkan kemampuan dasar ataupun untuk melanjutkan ke jenjang yang lebih tinggi. Keberhasilan pada jenjang sekolah dasar dapat menentukan keberhasilan pada jenjang pendidikan selanjutnya. Berdasarkan Pasal 67 Peraturan Pemerintah Nomor 17 Tahun 2010, pendidikan sekolah dasar berfungsi untuk: (1) menanamkandan mengamalkan nilai-nilaikeimanan, akhlak mulia, dan kepribadian luhur; (2) menanamkan dan mengamalkan nilai-nilai kebangsaan dan cinta tanah air; (3) memberikan dasardasar kemampuan intelektual dalam bentuk kemampuan dan kecakapan membaca, menulis, dan berhitung; (4) memberikan pengenalan ilmu pengetahuan dan teknologi; (5) melatih dan merangsang kepekaan dan kemampuan mengapresiasi serta mengekspresikan keindahan, kehalusan, dan harmoni; (6) menumbuhkan minat pada olahraga, kesehatan, dan kebugaran jasmani; serta(7) mengembangkan kesiapan fisik dan mental untuk melanjutkan pendidikan ke SMP/MTs atau bentuk lain yang sederajat. Menurut Teori Perkembangan Kog-nitif dari Jean Piaget, pada usia sekolah dasar yang dimulai usia 7 tahun, anak sedang berada pada tahap operasional konkret Santrock, 2014, Ghazi \& Ullah (2015). Pada tahap operasional konkret, aspek kognitif anak akan berkembang pesat, terutama yang berkaitan dengan penalaran logika. Oleh karena itu, harapannya sejak permulaan Sekolah Dasar, program kegiatan belajar di sekolah dapat menstimulasi dan memfasilitasi aspek penalaran logika tersebut. Perkem-bangan penalaran logika tidak hanya dikembangkan atau distimulasi melalui program akademik saja atau hal yang bersifat kognitif semata, namun melalui semua proses pendidikan yang ada di sekolah yang menstimulasi semua aspek perkembangan seperti fisik, kognitif dan bahasa, serta sosioemosinal yang terinte-grasi pada diri anak. Kesiapan dari semua aspek yang ada pada anak diharapkan dapat menunjang prestasi belajarnya di sekolah. 
Kesiapan individu akan membawa individu untuk siap memberikan respon terhadap situasi yang dihadapi melalui cara sendiri. Seperti yang diungkapkan oleh Slameto (2010) bahwa kesiapan adalah keseluruhan semua kondisi individu yang membuatnya siap untuk memberikan respon atau jawaban di dalam cara tertentu terhadap situasi tertentu. Kondisi tertentu yang dimaksud adalah kondisi fisik dan psikisnya, sehingga untuk mencapai tingkat kesiapan yang maksimal diperlukan kondisi fisik dan psikis yang saling menunjang kesiapan individu tersebut dalam proses pembelajaran. Kesiapan individu sebagai seorang peserta didik dalam belajar akan menentukan kualitas proses dan prestasi belajar peserta didik.

Berdasar informasi dari guru kelas 1 maupun panitia penerimaan peserta didik baru, menyampaikan bahwa kemampuan anak dalam menulis dan membaca sederhana menjadi persyaratan diterimanya anak menjadi peserta didik pada sekolah dasar Afifah dan Dwisusari (2016).

Kondisi-kondisi tersebut, menyiratkan bahwa kesiapan sekolah nampaknya sebagian orang tua dan pihak sekolah hanya menitikberatkan pada kemampuan kognitif saja, namun kurang menyentuh aspek sosial. Mereka masih belum mampu mengurus keperluan mereka sendiri maupun dalam beradaptasi di lingkungan sekolah yang baru

Pada usia kanak-kanak awal kematangan sosial ditunjukkan dengan perilaku antara lain: mampu menunjukkan sikap bekerja sama dalam kelompok, berani menampilkan diri sesuai dengan minatnya, dapat menunjukkan sikap berbagi, dapat bersikap sesuai norma lingkungan kecil, mampu bersikap simpati dan empati yang masih sederhana, dapat bersikap ramah, tidak egois, suka meniru perilaku positif lingkungannya, serta dapat memberi kasih saying pada orang yang dekat (Prihaningsih dalam Wulandari, 2008). Kematangan sosial yang dimiliki anak akan mempermudah dirinya untuk berorientasi dan bersosialisasi dengan dunia luar yaitu lingkungan masyarakat.

Menurut Teori Perkembangan Kog-nitif dari Jean Piaget, pada usia sekolah dasar yang dimulai usia 7 tahun, anak sedang berada pada tahap operasional konkret Santrock, 2014, Ghazi \& Ullah (2015). Pada tahap operasional konkret, aspek kognitif anak akan berkembang pesat, terutama yang berkaitan dengan 
penalaran logika. Oleh karena itu, harapannya sejak permulaan Sekolah Dasar, program kegiatan belajar di sekolah dapat menstimulasi dan memfasilitasi aspek penalaran logika tersebut. Perkem-bangan penalaran logika tidak hanya dikembangkan atau distimulasi melalui program akademik saja atau hal yang bersifat kognitif semata, namun melalui semua proses pendidikan yang ada di sekolah yang menstimulasi semua aspek perkembangan seperti fisik, kognitif dan bahasa, serta sosioemosinal yang terinte-grasi pada diri anak. Kesiapan dari semua aspek yang ada pada anak diharapkan dapat menunjang prestasi belajarnya di sekolah.

Berdasarkan serangkaian pemikiran teoritis dan hasil-hasil penelitian yang terjadi di lapangan, maka peneliti ingin mengetahui apakah prestasi belajar pada peserta didik kelas 1 Sekolah Dasar di bawah usia 7 tahun dapat dipengaruhi oleh kesiapan sekolah dan kematangan sosial.

\section{Metode}

Penelitian ini merupakan penelitian kuantitatif inferensial akan dilakukan untuk membuktikan hipotesis yang diajukan dalam penelitian ini. Karakteristik partisipan dalam penelitian ini yaitu peserta didik kelas 1 sekolah dasar yang ketika masuk SD berusia dibawah 7 tahun. Pelaksanaan pengambilan data dilakukan melalui prosedur perijinan ke orang tua wali murid yang diambil dengan Teknik Insidental Sampling.

\section{Instrumen penelitian}

\section{Prestasi belajar}

Prestasi belajar dapat dikatakan sebagai hasil yang diperoleh dari kegiatan pembelajaran di sekolah yang bersifat kognitif dan biasanya ditentukan melalui pengukuran dan penilaian nilai rapor. Rapor digunakan untuk mengumpulkan data variabel prestasi belajar. Penelitian ini menggunakan ratarata nilai rapor peserta didik kelas 1 semester 1 dan 2 . 
Philanthrophy Journal of Psychology

Vol 2 Nomor 2 (2018), 145-158

ISSN 2580-6076 (Print), ISSN 2580-8532 (Online)

\section{Kematangan Sosial}

Kematangan Sosial adalah kemampuan individu dalam menyesuaikan diri dengan lingkungannya sehingga membentuk kebiasaan yang membantu dalam kehidupan berkelompok dan membantu kemandirian sosialnya. Dalam penelitian variabel kematangan social diukur menggunakan Vineland Social Maturation Scale (VSMS). Alat tes ini dirancang oleh Doll berdasarkan aspek self-help, self-direction, locomotion, occupation,communication, dan sosial relation. Alat ukur ini teruji reliabilitas dan validitasnya. Hasilnya menunjukkan angka 0,90 untuk koefisien reliabilitas, sedangkan validitas menunjukkan koefisien 0,31 sampai 0,54.

\section{Kesiapan Sekolah}

Kesiapan Sekolah sifat atau kekuatan yang membuat seseorang dapat bereaksi dengan cara tertentu dan kesiapan mengandung arti kemajuan secara baik dan mendapatkan hasil yang memuaskan bila suatu tugas atau perlakuan diberikan. Dalam penelitian variabel kesiapan sekolah diukur menggunakan Nijmeegse Schoolbekwaamheids Test (NST). Instrumen tes yang digunakan adalah Nijmeegse Schoolbekwaamheids Test (NST) untuk mengukur kesiapan belajar di sekolah dasar. Instrumen NST yang digunakan memiliki koefisien reliabilitas Alpha Cronbach sebesar 0,851 dan terdiri dari 10 sub tes yang terdistribusi kedalam empat aspek kesiapan yaitu kesiapan fisik, intelektual, sosial, dan emosional. Kesiapan fisik meliputi pengamatan dan kemampuan membedakan, motorik halus, serta pengertian tentang ukuran, jumlah dan perbandingan; kesiapan intelektual meliputi ketajaman pengamatan, penga-matan kritis, konsentrasi, dan daya ingat; kesiapan emosional meliputi pengertian tentang objek dan penilaian terhadap situasi serta memahami cerita; dan kesiapan emosional meliputi pemahaman konsep dan konsentrasi.

\section{Teknik Analisis Data}

Sesuai dengan hipotesis yang diajukan maka teknik analisis data yang digunakan adalah Analisis Regresi 2 prediktor untuk mengetahui apakah prestasi belajar dapat dipengaruhi oleh kesiapan sekolah dan kematangan social dan apakah prestasi belajar dapat diprediksi berdasarkan kematangan sosial dan kesiapan sekolah. Sebelum melakukan analisis data dilakukan uji asumsi klasik regresi. 


\section{Hasil}

Tujuan utama dari penelitian ini adalah untuk mengetahui apakah prestasi belajar pada peserta didik kelas 1 Sekolah Dasar di bawah usia 7 tahun dapat diprediksi melalui kesiapan sekolah dan kematangan sosial. Rapor digunakan untuk mengumpulkan data prestasi belajar. Penelitian ini menggunakan rata-rata nilai rapor peserta didik kelas 1 semester dan 2. Alat tes VSMS berdasarkan aspek selfhelp, self-direction, locomotion, occupation,communication, dan sosial relation. Alat ukur ini teruji reliabilitas dan validitasnya. Hasilnya menunjukkan angka 0,90 untuk koefisien reliabilitas, sedangkan validitas menunjukkan koefisien 0,31 sampai 0,54 .

Sedangkan Instrumen NST yang digunakan memiliki koefisien reliabilitas Alpha Cronbach sebesar 0,851 dan terdiri dari 10 sub tes yang terdistribusi kedalam empat aspek kesiapan yaitu kesiapan fisik, intelektual, sosial, dan emosional. Kesiapan fisik meliputi pengamatan dan kemampuan membedakan, motorik halus, serta pengertian tentang ukuran, jumlah dan perbandingan; kesiapan intelektual meliputi ketajaman pengamatan, penga-matan kritis, konsentrasi, dan daya ingat; kesiapan emosional meliputi pengertian tentang objek dan penilaian terhadap situasi serta memahami cerita; dan kesiapan emosional meliputi pemahaman konsep dan konsentrasi.

Uji Heteroskedastisitas dilakukan dengan metode grafik yaitu dengan melihat pola titik-titik pada grafik regresi. Diperoleh hasil bahwa pada variabel penelitian terdapat pola tertentuyang teratur sehingga terjadi heteroskedastisitas. 


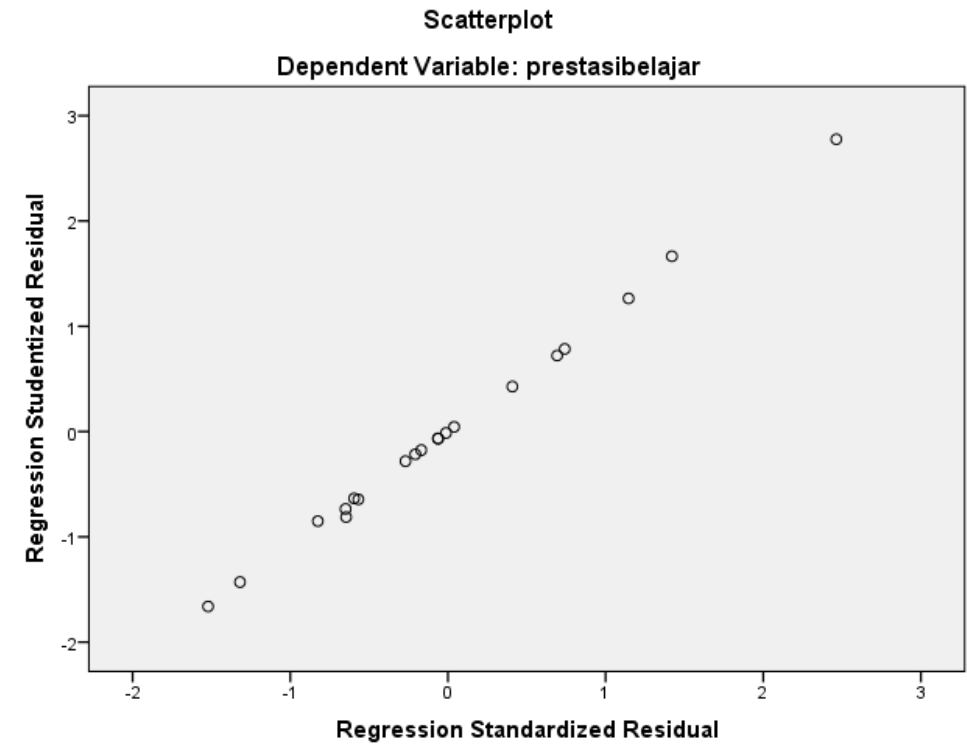

Gambar 1. Scatterplot hasil uji heteroskedastisitas

Uji Normalitas Residual menunjukkan bahwa model regresi memiliki nilai residual yang terdistribusi secara normal. Metode yang digunakan adalah metode grafik normal P-P Plot of regression standardized Nampak bahwa titik-titik menyebar sekitas garis dan mengikuti garis diagonal sehingga nilai residual dikatakan normal.

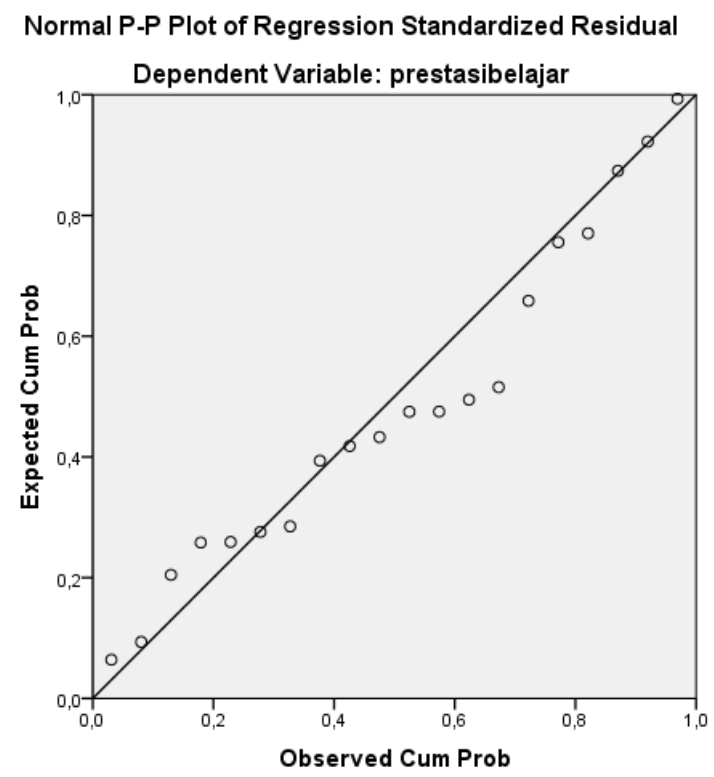

Gambar 2. Grafik uji normalitas residual 
Berdasarkan Uji Multikolenieritas diperoleh nilai Variance Inflation Factor $(\mathrm{VIF})=1,000(\mathrm{VIF}<10)$ dan nilai Tolerance $=1,000(\mathrm{~T}>0,100)$ sehingga dinyatakan bahwa tidak terjadi multikolinearitas antar variable bebas.

Tabel. 1.

\section{Hasil uji Multikolinearitas}

\section{Coefficients ${ }^{\mathbf{a}}$}

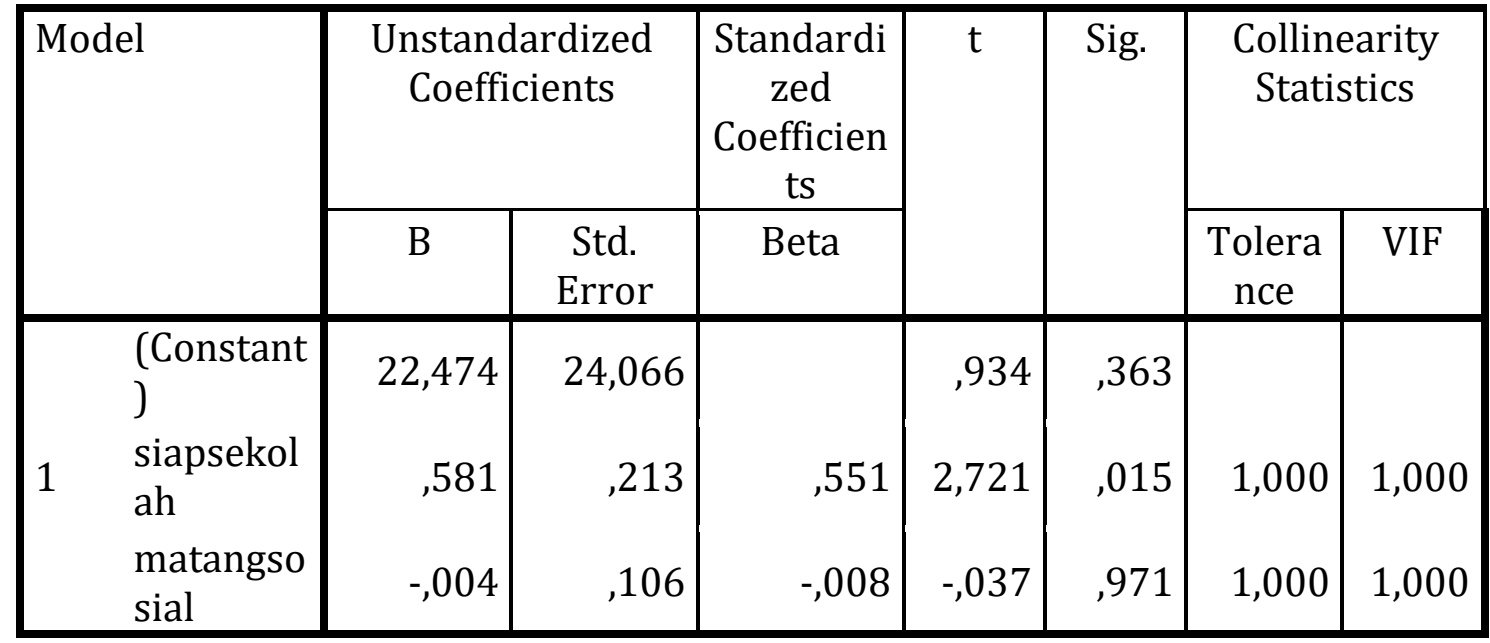

a. Dependent Variable: prestasibelajar

Uji Autokorelasi diperoleh data bahwa nilai Durbin-Watson (DW) 1,873 hal ini berarti nilai DW berada pada daerah antara dL $(1,100)$ dan dU $(1,537)$ sehingga tidak dapat dipastikan terjadi autokorelasi.

Tabel 2.

\section{Hasil uji Autokolinearitas}

\begin{tabular}{|l|r|r|r|r|r|}
\hline $\begin{array}{l}\text { Mode } \\
\mathrm{l}\end{array}$ & $\mathrm{R}$ & R Square & $\begin{array}{c}\text { Adjusted R } \\
\text { Square }\end{array}$ & $\begin{array}{c}\text { Std. Error of } \\
\text { the Estimate }\end{array}$ & $\begin{array}{c}\text { Durbin- } \\
\text { Watson }\end{array}$ \\
\hline 1 &, $551^{\mathrm{a}}$ &, 303 &, 222 & 5,09930 & 1,873 \\
\hline
\end{tabular}

a. Predictors: (Constant), matangsosial, siapsekolah

b. Dependent Variable: prestasibelajar

Setelah dilakukan uji asumsi maka prosedur selanjutnya adalah melakukan uji hipotesis dengan Teknik Regresi. Hasil menunjukkan bahwa koefisien Korelasi ganda (R) antara X1, X2 dan Y sebesar 0,551 dan $\mathrm{p}<0,05$ artinya ada hubungan antara kesiapan sekolah (X1) dan kematangan sosial (X2) dengan prestasi belajar 
(Y) dengan sumbangan sebesar $30.3 \%$. Secara parsial kesiapan sekolah berpengaruh terhadap prestasi belajar, tetapi kematangan sosial tidak memengaruhi prestasi belajar. Persamaan regresi $Y^{\prime}=22,474+0,581 X_{1}-0,004 X_{2}$

Tabel 3.

Hasil analisis Regresi

ANOVA ${ }^{\mathrm{a}}$

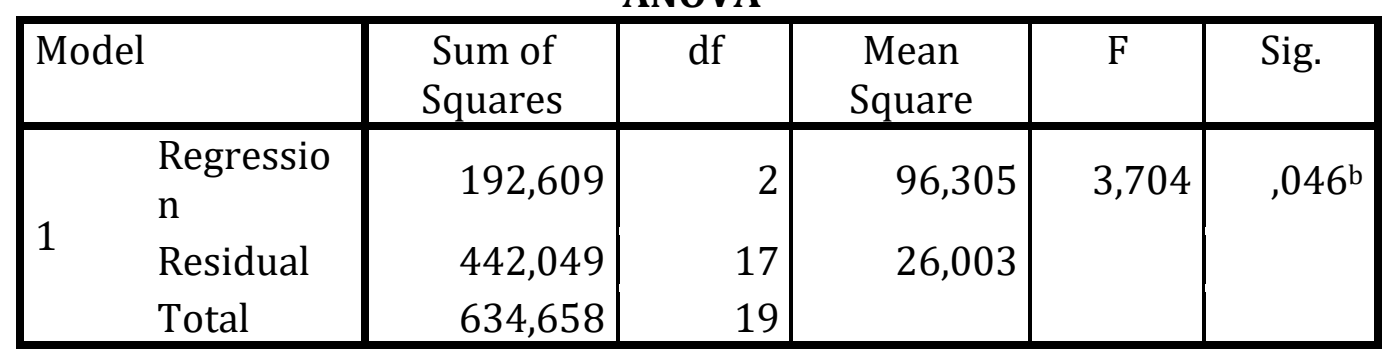

a. Dependent Variable: prestasibelajar

b. Predictors: (Constant), matangsosial, siapsekolah

Hasil menunjukkan bahwa variabel kesiapan sekolah dan kematangan sosial berpengaruh pada prestasi belajar. Namun demikian secara parsial variabel kematangan social tidak mempengaruhi prestasi belajar. Sumbangan kedua variabel terhadap prestasi belajar sebesar 30,3\% sedangkan variabel lain sebesar $79,7 \%$ adalah faktor lain. Faktor lain yang mempengaruhi diantaranya faktor inteligensi.

Prestasi seseorang ditentukan juga oleh faktor kecerdasan atau inteligensi. Walaupun mereka memiliki dorongan yang kuat untuk berprestasi dan orang tuanya memberi kesempatan seluas-luasnya untuk meningkatkan prestasinya, tetapi apabila kecerdasan mereka terbatas, maka prestasi yang mereka raih menjadi kurang maksimal. Hal ini dikarenakan inteligensi dan prestasi belajar adalah dua hal yang saling terkait . Menurut Vernon (2017), inteligensi memiliki tiga arti. Pertama, inteligensi merupakan kapasitas bawaan yang diterima oleh anak dari orang tuanya melalui gen yang nantinya akan menentukan perkembangan mentalnya. Kedua, istilah inteligensi mengacu pada pandai, cepat dalam bertindak, bagus dalam penalaran dan pemahaman, serta efisien dalam aktivitas mental. Ketiga, inteligensi adalah umur mental atau IQ (Intelligence Quotient). Inteligensi merupakan suatu gabungan dari beberapa fungsi atau 
kombinasi kemampuan untuk memahami gagasan yang kompleks, beradaptasi secara efektif terhadap lingkungan, belajar dari pengalaman, terlibat dalam berbagai bentuk penalaran, serta menggunakan pikiran untuk mengatasi hambatan atau mencari solusi. Dari beberapa kajian literatur, inteligensi diyakini sebagai salah satu prediktor terbaik prestasi belajar disebabkan karena inteligensi menunjukkan kematangan perkembangan dan merupakan salah satu faktor kognitif yang berupa potensi bawaan yang dapat berubah maupun berkembang seiring dengan praktik (pengasuhan atau usaha) yang pada akhirnya akan membentuk kecakapan dalam berperilaku (Singh \& Sinha, 2013) Inteligensi yang dimiliki anak memang terkait dengan faktor genetik, namun fakta bahwa lingkungan juga berperan menimbulkan perubahan-perubahan yang cukup berarti.

Secara bersamaan kematangan sosial dan kesiapan sekolah berpengaruh terhadapprestasi belajar, namun secara parsial kematangan sosial tidak berpengaruh terhadap prestasi belajar. Hal tersebut disebabkan karena kematangan sosial merupakan aspek non kognitif sedangkan kesiapan sekolah erat berkaitan dengan aspek kognitif seperti halnya prestasi belajar.

\section{Daftar Pustaka}

Afifah, D, R \& Hermawati Dwisusari, 2016, Profil Kematangan Sosial Anak Sekolah Dasar Awal se-Kota Madiun Ditinjau dari Vineland Social Maturation Scale, Jurnal CARE, Vol. 3, No. 2, Hal. 68-75.

Chaplin, 2011, Kamus Lengkap Psikologi, Jakarta : Raja Grafindo Persada.

Ghazi, S, R, \& Ullah, K., 2015, Concrete Operational Stage of Piaget's Cogntive Developmental Theory : An Implication in Learning General Science, Gomal University Journal of Research, Vol. 31, no 1, h. 78-89.

Halimah, N \& Fajar K, 2010, Kesiapan Memasuki SD pada Anak yang Mengikuti Pendidikan TK dengan Anak yang Tidak mengikuti Pendidikan TK di Kabupaten Kudus, Jurnal Psikologi UMK, Vol 1, no. 1, h. 1-8

Izzaty, R. E., Yulia A \& Farida, A. S., 2017, Prediktor Prestasi Belajar Siswa Kelas 1 SD, Jurnal Psikologi Fak. Psikologi UGM, Vol. 44, no. 2, h. 153-164.

Kazu, I. Y. 2009. The effect of learning style on education and the teaching process. Journal of Social Sciences. 5(2), 85-94. 
Kpolovie, P. J, Joe, A. I \& Okoto, T, 2014, Academic Achievement Prediction : Role of Interest in Learning and Attitude Towards School. International Journal of Humanities Social Sciences and Eduction. Vo. 1, no 2,h. 73-100.

Kustimah, 2008, Gambaran kesiapan Anak masuk Sekolah dasar Ditinjau ddari Hasil Tes NST, Bandung : Universitas padjajaran, http://www.pustaka.unpad.id.

Lawrence, A. S. A.,\& Vimala, A, 2012, School Environment and Academic Achievement of Standard IX Students, Journal of Educational and Instructional Studies in The World, Vol. 2, no. 3, h. 210-215.

Mulyani, D, 2012, Hubungan Kesiapan Belajar Siswa dengan Prestasi Belajar, Jurnal Ilmiah Konseling, Vol. 2, No. 1, h. 27-31.

Morrison, G, S, 2009, Fundamentals of Early Childhood, Ed. 5th (terjemahan Suci Ramdhonah dkk), Jakarta : Indeks.

Novitawati, 2013, Kesiapan Sekolah Anak TK Berbasis Model Pembelajaran Centtral (studi Kualitatif di TK Islam Sabilal Muhtadin Banjarmasin 2011), Jurnal PAUD, Vol.7, Ed. 1., h. 109-132.

Purwanto, N, 2007, Ilmu Pendidikan Teoretis dan Praktis, Bandung : Remaja Rosdakarya.

Singh, M. P., \& Sinha, J. (2013). Impact of spiritual intelligence on quality of life. International Journal of Scientific and Research Publications. 3(5), 1-5.

Slameto, 2010, Belajar dan Faktor-Faktor Yang Mempengaruhinya, Jakarta : Rhineka Cipta.

Santrock, J, W, 2014, Child Development (14 th ed.), New York : McGraw-Hill Publishing.

Wulandari, A, 2008, Perbedaan Kematangan Sosial Anak Ditinjau dari Keikutsertaan Pendidikan Pra Sekolah (Play Group). Tesis (online), www.distrodoc.com/316138. 